\title{
DERIVATIVES OF GENERALIZED MEANS
}

\author{
SILVIA TOADER
}

Abstract. A generalized mean is a reflexive positive function of two positive variables. We study the partial derivatives of first and second order of a generalized mean. We also prove that a homogenous generalized mean is a mean on a limited interval. The results are useful in the researches related to the generalizations of the arithmetic-geometric mean.

Mathematics subject classification (2000): 26E60.

Key words and phrases: generalized mean, arithmetic-geometric mean, mean on a limited interval.

\section{REFERENCES}

[1] S. Abramovich, J. PeČArić, Functional equalities and some mean values, J. Math. Anal. Appl. 250 (2000), 181-186.

[2] J. ACZÉL, L. LOSONCZI, Z. PÁLES, The behaviour of comprehensive classes of means under equal increments of their variables, Gen. Ineq. 5, Oberwolfach 1986, Internat. Sem. Numer. Math. 80 (1987), 459-461.

[3] P. S. Bullen, D. S. Mitrinović, P. M. VAsić, Means and Their Inequalities, Reidel, Dordecht, 1988.

[4] D. M. E. Foster, G. M. Phillips, A generalization of the archimedean double sequence, J. Math. Anal. Appl. 101 (1984), 575-581.

[5] Y.-H. KIM, On some further extensions of the characterizations of mean values by H. Haruki and Th. M. Rassias, J. Math. Anal. Appl. 235 (1999), 2, 598-607.

6] G. TOADER, Some remarks on means, Anal. Numèr. Théor. Approx. 29 (1991), 1-2, 97-109.

[7] Silvia Toader, T. M. Rassias, G. Toader, A Gauss type functional equation, Intern. J. Math. Math. Sci. 25 (2001), 9, 565-569. 